\title{
Life Skill Education on Salafiyah Islamic Boarding School in Indonesia (Learn From Pesantren Walindo Manbaul Falah Salafiyah )
}

\author{
A.M. Wibowo ${ }^{1}$, Dwi Istiyani ${ }^{2}$ \\ attara.wibowo@gmail.com¹,dwi_istiyani@walisongo.ac.id² \\ Religious Research, Development and Training Agency, Ministry of Religious Affair Republic \\ Indonesia, Kantor Balai Litbang Agama Semarang Jl. Untungsuropati Kav.70 Bambankerep Ngaliyan \\ Semarang Indonesia ${ }^{1}$, \\ Universitas Islam Negeri Walisongo Semarang, Fakultas Ilmu Tarbiyah dan Keguruan, Jl. Prof Hamka \\ Ngaliyan Semarang ${ }^{2}$
}

\begin{abstract}
Salafiyah Islamic boarding school is Indonesia's oldest educational institution. Besides teaching Islamic science, it also teaches life skills. This article is based on a qualitative study that aimed to analyze life skills education in salafiyah Islamic boarding school in the Pekalongan regency. The findings of this study are salafiyah Islamic boarding school instilled life skills education through a hidden curricula on everyday culture. Life skills education produces learners who are mutafaqqih fiddiin and willing to live freely, self-reliant, and self-sufficiency by maintaining the importance of honesty, simplicity, dignity, and balance of life between worldliness and the hereafter. Carpentry, planting, fisheries, irrigation, steering wheel, business, and water-making Reserve osmosis are examples of life skills education taught at salafiyah Islamic boarding school. Because of its self-sufficiency, the schooling of life skills in salafiyah Islamic boarding school can elevate the student's life and reduce the unemployment rate nationally.
\end{abstract}

Keywords: salafiyah Islamic boarding school, life skills education, self-suffcient, sincere, simple, equilibrium of life.

\section{Introduction}

Islamic boarding schools (also known as pesantren) are a native Indonesian educational institution that has a significant benefit in terms of its research heritage, which is one of the great values, as well as the dissemination side and internalization of Muslim morals. Pesantren, as an indigenous/local genius of Indonesian educational institutions, has many parallels with conventional Islamic educational institutions in the Islamic world region [1] [2]. The similarity thinks it is not only at the institutional level and its relation to the social environment, but also to the character and characters of the science. Pesantren is a traditional Islamic educational institution has the vision to study with deepen comprehend, internalize and practice Islamic religious teachings by emphasizing the importance of religious moral as a guideline for 
everyday conduct[3]. In the book titled Esai-Esai Intelektual Muslim Pendidikan Islam has revealed that the science of Pesantren is understood as an institutional function that has three main roles namely the transmission of Islamic sciences, the preservation of Islamic traditions, and the construction of prospective scholars. Nevertheless, according to the authors other than institutional of pesantren also instilled the function of self-reliance and entrepreneurship soul.

Education in pesantren does not only give santri (call for the student in pesantren) who have a mutafaqqih Fiddin (expertise on Islamic knowledge), but also students who can survive and independently when they come out and graduate as ulama (Islamic scholar) from the education of Islamic boarding school or pesantren. Education especially in salafiyah pesantren has a characteristic of other than teaching religious sciences, in this institution also teaches about life skills so that the graduates are not only religious experts but also creative, selfsufficient and self-sufficiency. This is because education in salafiyah pesantren not only equips the students or santri through hard skills (science) but also teaches of life skills education. There have been many graduates who become entrepreneurs or entrepreneurial after graduating from pesantren. The graduates from this institution prefer independent living than working in a formal sector like industrial or government employee.

In comparison to the government's comprehensive education, there is a high rate of unemployment. According to data from the Indonesia Central Bureau of Statistics published in Kompas on November 5, 2019, the number of unemployed people in Indonesia rose in 2019 from 7 million to 7.05 million, with vocational school accounting for 10.4 percent and college accounting for 5.4 percent [4]. Formal education graduates are unemployed because their orientation is to serve in formal industries such as manufacturing or another formal field.

The education model in pesantren does not only teach the science of religion but also teaches knowledge about life skills. Islamic education in pesantren should be able to prepare human resources not only as the recipient of the global information flows, but should also provide them to process, adapt and develop everything that is received through the flow of information, namely human being creativity, and productive [5]. The process of education in pesantren is to realize graduates who are expertise in Islamic knowledge, human beings who believe and fear God and have a broad knowledge of religious sciences. Besides, Islamic boarding schools as a place to produce scholars with the quality of Islam, faith, scholarship, and moral students are also expected to build themselves with the surrounding communities. Pesantren also aims to create an independent Muslim man who has self-reliance and independent.

This article base on qualitative research that aims to describe and analyze the education of life skills in one of the salafiyah Islamic boarding schools or pesantren at the Pekalongan regency. As the subject research is Pesantren Walindo Manbaul Falah is one of the huts in this regency. The pesantren is located in Siwalan district of Pekalongan. By demographic the majority of the population is Muslim. This can be proved by data from the Pekalongan's Central Bureau statistic in 2019 related to the number of Muslim population amounting to 863,692 from 867,573 or $99.5 \%$ of the total population is a religion of Islam [6]. Data EMIS (Education Management Information System) the Directorate of Boarding Schools noted that there are at least 70 boarding schools in the regency of Pekalongan [7]. Not wrong if Pekalongan is known as Kota Santri (islamic scholar city). The problem in this research is how life skill education on Pesantren Salafiyah Walindo Manbaul Falah in providing the santri (students) so that when graduates of Pesantren in the public society as candidates for scholars who expertise in Islamic religion and independent in his economic life and living life around it. Quite apart from that, this study aims to obtain an overview of and review the life skills education provided to students at Salafiyah Walindo Manbaul Falah's Pesantren. As the subject life skill program on pesantren, 
the approach study using depth interviews with main informants such as Kyai, asatidz, and santri. Observation and reporting are also used to collect information about how the life skills program is applied in pesantren's daily lives.

\section{THEORETICAL FRAME WORK}

The word education in Arabic is tarbiyah with the verb Rabba meaning to educate or nurture [8]. With another sentence of tarbiyah is the process of development and guidance of the body, mind and soul that is done continually so that Mutarabbi (a student) can mature and independent to live in the community [9]. So education in Islam is tutoring by educators on the physical, spiritual and resourceful development of students so that they can form a good Muslim personal. Education is a conscious endeavor undertaken by families, communities, and governments through mentoring, teaching, and training, which takes place in schools and outside of school for Life to prepare learners to play a role in various living environments on a regular basis for the future [11]. Education is key to living life, with human education gained personal, social and vocational Skills [12] [13].

In the Indonesian context as stipulated in Law No. 20 of 2003 on the National Education System, said a conscious and well-planned endeavor to create a learning atmosphere and learning process so that students actively develop their potential to possess the spiritual power of religion, self-control, personality, intelligence, noble morality, and skills necessary to himself and society [14]. From some of theories it can be said that education is a conscious and systematic effort to attain the level of life or for better progress both physically and spiritually done in school and outside the school so that people become mature and independent to live in the community. To accomplish this, a system or curriculum is synergized with educational ideals. Educational life skills are one of the non-formal educational programs that have an important role in the ability to equip the citizens to be able to live independently. The World Health Organization makes the definition of educational life skills in the form of a skill that has later citizens learn to have the ability to adapt and behave positively, allowing a person to be able to face various demands and challenges in a more effective life [15]. The concept of life skills education has long been the concern of experts in curriculum development. Robert $\mathrm{R}$ Tyler and Hilda Taba, they suggested that life skills are one of the focus of analysis in the development of an educational curriculum that emphasizes on the life skills and work [16] [17]. If it is associated with education in Islamic boarding school, the development of life skills at least 5 aspects are; Relevant skills to master students, learning materials according to the level of development, learning activities and students, activities to achieve competence, facilities, tools and learning resources adequate by boarding schools, as well as abilities that can be applied in the life of students.

Life skills have a broader meaning than just a vocational skill or skill to work with. Life skills are essentially a person's ability to fight for their lives. Therefore, the development of a person's life skills needs to be in the process through education and exercises that are essentially aiming to acquire basic abilities. Because without basic ability, it would be difficult to develop his life skills [18] [19]. The essential of educational life skills is an attempt to minimize the difference between the education world and real-life so that education will be more realistic and more contextual with everyday real-life values. The role and function of education are to prepare learners to be able to develop life as a person, for society, state, and nation, and to prepare students to follow higher education. Education of life skills is a process of learning with the aim 
of giving citizens (pupils or students) learn to have the knowledge, skills and attitudes needed in entering the workforce both works independently (entrepreneurial) and/or work on a production company/service with an increasingly viable income to meet the needs of its life. In addition, education of life skills can motivate and create a high work ethic for citizens to learn in order to produce superior works and to compete in the global market. The education of life skills must be equality with a high level of awareness about the importance of education for himself and for his family members in the future based on values of sincerity, simplicity, independence and balance. Many varieties related to life skills such as job-picking skills, work planning, job skills preparation, skill training, competency mastery, running a profession, awareness to master various skills, skills mastering and implementing technology, designing and implementing job processes, and producing goods and services [20]. Related to the education of life skills, education in boarding schools especially Pesantren Salafiyah boarding school apparently changed implement it long before the state of Indonesia is independent. Carrying out life skills education in pesantren evident from cultural values implanted in components pesantren cultural ideals include honesty, simplicity, freedom, and balance [21]. Simplicity is a non-extravagant way of living, honesty is the mindset of enjoying what is earned, freedom is the desire to survive without relying on others, and the liquid equilibrium of self-control ability [22]. The qualities of these life skills are instilled in students through the truthful and pesantren curricula.

Islamic boarding schools are centers of Islamic religious education with a growing and accepted population. As the subject of schooling, a Santri or student provides religious education through a method of study or madrasah that is completely under the sovereignty of the leadership of an individual or many individuals. Kyai (the call for an Islamic boarding school leader [25]. Pesantren is a traditional Islamic educational institution that exists to regenerate or create future scholars who are mutafaqqih fiddiin [26]. The Graduate School of salafiyah Islamic boarding school is expected to absorb, study and practice Islamic religious teachings by emphasizing the moral importance of Islamic religion as a guideline for daily living both individually and taught to the public. Pesantrens are one of the educational subsystems that have special characteristics. The model of education implemented by the pesantren legally, recognized by the spirit of law No. 20 of 2003 on the national education system. Salafiyah Pesantren is an Islamic educational institution with a boarding system. Pesantren consists of five components: pondok, which is a boarding house, Kyai (the leader of boarding school), Kitab Kuning, which is a classical Islamic book, Mosque, and santri or student [27]. Salafiyah Islamic boarding school still prioritizes and preserves its original form by merely teaching the Kitab Kuning written by Salaf holy scholars in the Arabic language known as pegon. The application of the education system and the instruction in salafiyah pesantren vary from one another. The Implementation of education system and teaching in salafiyah pesantren differs from one another pesantren. There is no uniformity in the organizing of education and teaching. In some boarding schools salafiyah, the system of education and teaching is increasingly changed because it is influenced by the development factor of education and the demands of the community in the environment of pesantren salafiyah itself. Some still maintain the original education and teaching system [29].

\section{LIFE SKILLS EDUCATION IN SALAFIYAH PESANTREN}

\subsection{Learn from salafiyah Walindo Manbaul Falah's Pesantren}


Walindo Islamic boarding school has the full name Walindo Manbaul Falah Siti Zaenab Kyai Parak Bambu Runcing IV Berbaur, but the famous name of this pesantren is Walindo. The vision of this institution is to prepare Islamic cadres, creative and innovative. While the mission of this pesantren is to build santri's or student's mental-spiritual with the faith of Islam and Ihsan (beneficence), educate the students to develop the creativity of self-reliant life, gave the knowledge that develops innovative and argumentative thinking. The teaching and learning activities were initially followed only by the community, especially the children around the boarding. Following the later students who came from various areas in the former residency of Pekalongan The specialty of Walindo Islamic boarding school is free of charged cost from buildings money, eating, and drinks daily. Santri only bought a study of their success as Kitab Kuning, books, and stationery. The boarding now has twelve men's rooms and eleven women's rooms, with about 600 male and female santri. Donors offered funds for the expulsion of students and pesantren. Walindo Manbaul Falah life skills education Islamic boarding schools instill ideals such as honesty, simplicity, freedom, and life balance between this world and the hereafter. The educational values of life skills are listed below based on research findings.

\subsubsection{Sincerity}

Although the official santri study at the pesantren, education about the principles of honesty has been implanted in the Walindo Islamic boarding school. Santri was unable to associate with Kyai, Asatidz (the appeal for teachers in pesantren), and fellow students (santris) because he had to be honest and follow the laws of pesantren in terms of Ethics. In terms of the pupils, they are also taught that they should not wear jewelry or branded clothes, should not have cell phones, should not watch television or radio, and so on. It is intended for students to be used to clear the worldly things of ujub (arrogant). Pesantren always instilled the soul of sincerity in the students to be "sepi ing pamrih" (not driven by certain desires) and do solely for worship. Santri in pesantren is not charged a penny to pay asatidz (teachers). It is solely because of the sincerity of the pesantren and donors to finance the education in pesantren. Therefore, the pesantren also seeks to embed the value of sincerity to the students to be willing to receive lessons given by Asatidz. Because if until the students pay Asatidz then feared impact on the diminishing sincerity of the Asatidz to charity teacher in the form of science. Life skills education about the values of sincerity according to the Islamic Pesantren Walindo is the description of the curriculum of the book Kifayatul Atqiya. In that book teaches human deeds are cleaned of things that are $u j u b$ or exhibitionists. All charity human deeds are done merely to hope the mercy from God. The result is all gestures in the pesantren walk in an atmosphere of deep sincerity. Kyai and teachers sincere in teaching, the students sincerely in the study of science, the head of pesantren also sincere in assisting students in the form of mentoring. Expectations from boarding schools remain embedded in the students after graduating from boarding school.

\subsubsection{Simplicity}

The educational values of simplicity are always implanted in daily life in the environment of boarding schools. Since the beginning of admission became a student in the Walindo Islamic boarding school, students were released from the social status, the status of its economy. Pesantren does not treat a different student from poor or wealthy parents, even the son of great Kyai from other boarding schools who study in Walindo is treated similarly to students of an ordinary class. Even since the first day entered in Pesantren all the santribeing "impoverished" by the Pesantren. In being "impoverished" the intention that students should not keep money privately. It is to avoid unkind intentions from other students or santris. It is also prohibited for the santris to wear branded clothing. Every day, students should wear sarongs, skirts, and white peci or kopiah (the headcover is made of fabric and so on, with the form tapered 
both ends) or Skullcap, whereas female students should not wear powder, rings, or other accessories. Another manifestation of the importance of simplicity is a two-times-daily diet and fasting habit. Material on simple living can also be found in the Tafsir (Qur'anic commentary book) in Surah Al-Furqon verse 67, which states that parents should not spend money on lavishing riches on their children but should also not be stingy. The Values of simplicity deliberately grown on the spirit of students in the Walindo salafiyah Islamic boarding school to train the description of students, instill strength, steadfastness in the face of all difficulties, and come to feel the misery of the future someday. More than that, simplicity can also create a sense of solidarity, feel the beauty of togetherness among the students themselves. Simplicity does not mean poor or destitute life, but simple is a human far from the sense of riya (arrogant) and $u j u b$ (show of).

The practice of simplicity is intended to express the greatness of the soul, is not afraid of being poor, is full of struggles, and never gives up on studying the faith. Santri are trained to live abstinence from religious studies in all conditions to become mutafaqqih fiddiin scholar candidates who live simply, are not proud, and remain modest when they graduate from Islamic boarding schools and in society. A student can learn the wisdom of life or a lesson on simplicity by practicing living a simple life. By training, a simple life student can pluck the wisdom of life or lessons on simplicity. The science of simplicity is not only a theory but should be practiced for students when graduating and plunging into society as prospective scholars can face life in any situation and condition in society. The science of simplicity is not only theory but should be practiced for students when graduating and plunging in society as prospective scholars can face life in any situation and condition in the midst of society.

\subsubsection{Self-reliance}

During their first day at Pesantren Walindo, students have had to learn individually and take care of themselves without relying on others. Self-reliance activities are important for special santris and pesantren in general to protect their interests. With self-reliance drills, students aspire to never rely on the support and mercy of others. From the first day of the whole santri in preparation for self-sufficiency, washing and ironing their own clothing, and so on. However, in terms of morning and evening meals are still provided by the boarding school in the form of Mayoran which is one tray is for 4-6 santris. Life skill education in the form of values and self-reliance training provided by boarding school is to provide training and work practices such as carpentry, agricultural, farming, fisheries, business, steering wheel, making reserve osmosis water (RO Water) and so forth. Quite apart from vocational skills, the self-reliance exercise for other students takes the form of a da'wah practice in the social group to supplement or replace the Kyai or Asatidz who are unable to fill da'wah practices in the social community. This tradition of da'wah is to put the santri's mental and practical understanding of religious sciences and Kitab Kuning (Islamic classical manuscript book) to the test. Santri was also urged to use his wisdom to invite the community's society to change the people's lives through the practice of da'wah. Da'wah is the obligation of people who are religious and santri are the products of the pesantren that is a kind of the mutafaqqih Fiddin or the vast people of religious sciences.

In practice the da'wah students must convey the sciences that have been mastered. The Koran, Hadith, Tafseer of the Holy Koran, Biography of the Prophet, Fiqh, Arabic language, and another Islamic classical manuscript book are among the origins of religious sciences taught at the Walindo Islamic boarding school. Indeed, since Formal Diniyah education is mandated in Walindo education, life skills in the form of vocational skills have been reduced. Students are increasingly expected to master the Kitab Kuning formally. However, boarding school allows students to develop education life skills such as carpentry, cultivating, cooperative pesantren to 
learn business, agriculture, and so on for students who need the inclusion of vocational education. The practice of carpentry is done by the students when the boarding school builds mosques. All the mosque construction is done by the students who are purely studying in nonformal or do not follow the Education Diniyah Formal. They learn and practice field how to calculate, measure, stir cement, put up bricks, make iron columns for dak, casting, and other things related to building. In the field of farming and fisheries students are taught to learn to nurture farm animals like fish, chickens, goats, and cows belonging to the pesantren either in the pesantren or outside the pesantren.

Students learn and experience farming by making animal feed, foraging for grass, learning about pathogens in livestock and fisheries, and so on. Santri from Walindo teaches how to farm and garden properly in agriculture and plantations. They research and cultivate the area together, using pesantren assets such as rice fields and gardens. Apart from carpentry, forestry, animal husbandry, and fisheries, students are taught how to make RO (reverse osmosis) drinks. Starting with the introduction of the equipment and how to operationalize the RO water-making equipment. Santris are also given the ability to learn to drive a car. Santri is qualified to drive cars and repair minor car damage. Kyai used to invite Santri who could bring a car to drive to stay in touch or preach in the field or metropolitan area. Santris are educated in the business sector to develop a trading spirit through the management of corporate pesantren. Through the cooperative boarding school, students were trained to compose the book, calculate efficacy and money out, calculating capital and profit, and so forth related to the business.

The provision of life skill education by Walindo Islamic boarding school is one of the efforts to establish student self-reliance so that someday when graduating from pesantren and live in society after study on pesantren becomes independent, have entrepreneurs but do not escape the values of sincerity, and simplicity. But the more prominent is the santri can become scholars, Da'i or preacher and become role model of a society that devoted himself in the way of Allah in order to invite mankind in the teachings of good religion. The skill of the graduate of pesantren salafiyah is merely a support facility in order to preach the way of Allah.

\section{DISCUSSION}

From the description of implementation of life skill education on the subject research Walindo Islamic boarding school (pesantren Walindo) Pekalongan can be analyzed that Salafiyah boarding school in addition to providing Islamic religious sciences also prepare students with life skill in form of vocational education as a provision to face the future after graduation education in pesantren and live into society. Thus, in addition to mastering the knowledge of Islamic religion comprehensively graduates Salafiyah Pesantren also has a provision of skills to live independently in the community as well as citizens. Graduates of pesantren Salafiyah may not work in the formal sectors such as civil servants, enterprises (BUMN), private companies, and in the sector of the industry that requires the requirement of a formal education diploma. This is because the Islamic boarding school is only recognized by the government as a non-formal educational institution, except that the Pesantren run Education Diniyah Formal programs. Nevertheless, not all students in the Salfiyah Pesantren Walindo attended Education Diniyah Formal because the base wanted to retain the purity of his salafiyah.

Life skills Education in Salafiyah Pesantren is a hidden curriculum, meaning there is no special learning administration such as competency standards, basic competencies, and the standards of the competency of the graduates in a factual curriculum at a formal educational 
institution. This hidden curriculum goes with the culture of boarding school. Thus in addition to being someone who expertise in Islamic science, even become a scholar who has mastered the Islamic sciences academically and its rules comprehensively and the provision of life skills in the form of carpentry, agriculture, farming and fisheries, business, steering wheel, and RO water making, hope is a graduate of pesantren salafiyah have personal skills in the form of personal skills, self-analysis skills, rational thinking skills, social skills of vocational skills. If it is achievable, then the dependent factor on the existing job field can be lowered, which means that national productivity will gradually increase. Through working directly in a salafiyah Islamic Boarding school, students will learn about the ideals of daily life, so that when they graduate and move from pesantren, they will be capable, willing, and qualified to run the survival of life in the future. As a result of the salafiyah pesantren's teachings, students will live a life of favor and peace, and be able to solve life's problems with honesty, earthiness, freedom, and balance.

As ideals instilled in pesantren, academic and vocational abilities are wrapped in soul honesty, humility, freedom, and a harmony of life between worldliness and the hereafter. Graduates of pesantren salafiyah would be able to solve the challenge of living as individuals and as members of a community based on the Islamic religious teachings taught at salafiyah Islamic boarding school. Santris or students in Islamic boarding schools may recognize the issue of life, either individually or by others, discover solutions to challenges, act on the threats posed by the danger based on what is known, which is based on the religious values learned in salafiyah Islamic boarding school.

\section{CONCLUSSION}

Life skills education in Pesantren is taught by a graduate of an Islamic scholar who is mutafaqqih fiddiin (scientist on Islamic studies) who has a spirit of honesty, simplicity, freedom, and balance between the needs of the world and the hereafter. Based on a summary and study of life skill education at Pesantren Salafiyah This study concluded that life skills education in Pesantren is taught by a veiled program in everyday culture in Salafiyah Pesantren. Life skills education, such as carpentry, agricultural, farming, fisheries, business, steering wheel and vehicle, making reserve osmosis water (RO Water), and so on. This is a provision made by pesantren to help students plan for independent life, and science awareness is valuable to the society.

\section{References}

[ADDIN Mendeley Bibliography CSL_BIBLIOGRAPHY 1] Azra A. Pendidikan Islam Tradisi dan modernisasi di Tengah Tantangan Milenium III. Jakarta: Kencana Prenada Media Grup; 2012.

[2] Fadjar M. Visi Pembaruan Pendidikan Islam. Jakarta: Lembaga Pengembangan Pendidikan dan Penyusunan Naskah Indonesia / LP3NI; 1998.

[3] Azra A. Esai-Esai Intelektual Muslim Pendidikan Islam. Jakarta: Logos Wacana Ilmu; 1999.

[4] Kompas. BPS: Pengangguran Meningkat, Lulusan SMK Mendominasi. 5 November 2019 [Internet]. 2019; Available from: https://money.kompas.com/read/2019/11/05/155358926/bpspengangguran-meningkat-lulusan-smk-mendominasi

[5] Faisal JA. Reorientasi Pendidikan Islam,. (Jakarta: Gema Insani Press; 1995.

[6] Indonesia S data. Jumlah Penduduk Menurut Agama di Kabupaten Pekalongan [Internet]. Data Indonesia Dalam Satu Portal. 2019. Available from: https://data.go.id/dataset/jumlah-pendudukmenurut-agama-di-kabupaten-pekalongan 
[7] Direktorat PP. Daftar Pesantren di Indonesia [Internet]. MORA. 2020. Available from: https://ditpdpontren.kemenag.go.id/pdpp//loadpp?loadpp=\&id_kabupaten=3326\&id_provinsi=3 3 \&page $=14$

[8] Al-Thabary AJMI, Jaris. Jami'ul Bayan 'an Ta'wil ayat al-Qur'an. Dar al-Fikr,. Beirut: Dar alFikr; 1988.

[9] Ma'zumi S and N. Pendidikan Dalam Perspektif Al-Qur'an Dan Al-Sunnah: Kajian Atas Istilah Tarbiyah, Taklim, Tadris, Ta'dib dan Tazkiyah. TARBAWY Indones J Islam Educ. 2019;6(2):194-209.

[10] Dale E. Audio Visual Methods in Teaching. New York: The Dryden Press; 1969.

[11] Konstelnik MJ et. all. Teaching Young Children Using Themes. United States of America: Good Years Books; 1991

[12] Smith JT. Early Childhood Development: A Multicultural Perspective. third edit. Ohio: Upper Saddle River; 2003.

[13] Undang-Undang Nomor 20 Tahun 2003 tentang Sistem Pendidikan Nasional. 2003.

[14] Ministry of Education and Culture. Pendidikan Kecakapan Hidup. 2004.

[15] Tyler WR. Basic Principles of curiculum and instruction. Chicago, USA: University of Chicago Press; 1949.

[16] Taba H. Curriculum Development. Theory and Practice. New York: Harcourt, Brace and World.; 1962.

[17] Satori D. Implementasi Life Skills dalam Konteks Pendidikan di Sekolah. J Pendidik dan Kebud. 2002;34(8).

[18] Noor AH. Pendidikan Kecakapan Hidup (Life Skill) Di Pondok Pesantren Dalam Meningkatkan Kemandirian Santri. Jurnal Empower. 2015;3(1).

[19] Wahab R. Reformulasi Inovasi Kurikulum: Kajian Life Skill Untuk Mengantarkan Peserta Didik Menjadi Warga Negara Yang Sukses. TA'DIB. 2012;XVII(2):217-42.

[20] Wibowo AM., And Ahmad Mutkhib and Titi Isnaini Fauzah and Marimati mawardi And Nurul Huda. The Regeneration of Ulamas Moderate and Tolerant Through Education Dinyiah Formal in Salafiyah Pesantren. In: International Conference Religious and Education (INCRE 2019) [Internet]. Bintaro: European Union Digital Library (EAI); 2020. Available from: https://eudl.eu/doi/10.4108/eai.8-10-2019.2294509

[21] Kbbi daring. Kamus Besar bahasa Indonesia [Internet]. 2019 [cited 2019 Mar 11]. Available from: https://kbbi.kemdikbud.go.id/entri/paham

[22] Arifin M. Kapita Selekta Pendidikan ( Islam dan Umum). Jakarta: Bumi Aksara; 1991.

[23] Wibowo AM., And Ahmad Muntakhib and Titi Isnaini Fauzah and Marimati mawardi And Nurul Huda. The Regeneration of Ulamas Moderate and Tolerant Through Education Dinyiah Formal in Salafiyah Pesantren. In: INCRE (international Conference Religion and Education) [Internet]. Tangerang: EAIResearch MeetInnovation; 2020. Available from: https://eudl.eu/doi/10.4108/eai.8-10-2019.2294509

[24] Dhofier Z. Tradisi Pesantren Studi Pandangan Hidup Kyai dan Visinya Mengenai Masa Depan Indonesia. Jakarta: LP3ES; 2013.

[25] Direktorat PP. Pedoman Pondok Pesantren Salafiyah,. Jakarta: Ministry of religious Affair of Republic Indonesia; 2009. 